\title{
The Faculty Building about Voice Teachers of Pop Songs in Southwest University, China
}

\author{
Yanxi Chang \\ College of Music, Yunnan Arts University, Kunming, China \\ Email:54165796@qq.com
}

How to cite this paper: Chang, Y. X. (2021). The Faculty Building about Voice Teachers of Pop Songs in Southwest University, China. Art and Design Review, 9, 100-107.

https://doi.org/10.4236/adr.2021.91009

Received: December 30, 2020

Accepted: February 22, 2021

Published: February 25, 2021

Copyright $\odot 2021$ by author(s) and Scientific Research Publishing Inc. This work is licensed under the Creative Commons Attribution International License (CC BY 4.0).

http://creativecommons.org/licenses/by/4.0/

(c) (i) Open Access

\begin{abstract}
This paper was written from dissertation "A Study of the Undergraduate Curriculum for Voice Major Program in Popular Songs in Selected Normal Universities in China." The objectives are to improve the construction of voice teachers in the pop singing direction about undergraduate stage in Southwest University. The study employs the qualitative research methods and data from the fieldwork. Data for this investigation were collected from both field work and document analysis in Southwest University in China. The results are following: 1) The educational structure of full-time teachers in pop song direction of voice major needs to be improved; 2) The comprehensive quality of the teachers needs to be promoted; 3 ) The reserve of knowledge needs to be broadened. On this basis, the author puts forward the methods to improve the faculty building of voice teachers in pop singing direction in Southwest University in China by combining the discussion and fieldwork investigation.
\end{abstract}

\section{Keywords}

Faculty Building, Voice Teachers of Pop Songs, Southwest University

\section{Introduction}

In the long-term teaching and research of pop singing performance, and long-term study of singing performance in the normal universities, the author always pays attention to the curriculum of pop singing performance program. In reality, the lack of theoretical research on undergraduate curriculum of pop singing performance in the normal universities makes the author deeply to feel the importance and urgency of construction of the voice teacher on pop singing program.

The author went to Southwest University for the fieldwork in 2019. Voice program of popular songs is in music performance department. In 2005, music 
performance major was opened. The basic supporting disciplines of music performance major are musicology, music education, music psychology, music aesthetics, etc. With the improvement of people's cultural and living standards and their desire for traditional culture, people's demand for music works and performing talents, is growing day by day. Especially for primary and middle school teachers, vocal music ability, piano ability, instrumental music ability and the ability to organize a band have almost become one of the necessary conditions for music teachers. After graduation, students of this major can enter art troupes, colleges and universities, primary and middle schools and other relevant institutions and schools, with good employment prospects

(http://www.swu.edu.cn/).

In 2012, voice program of popular songs is opened in music performance major. There is no separate course training plan for the voice program of popular songs in Southwest University, so it is included in the music course training plan for the voice performance program in Southwest University. Therefore, I summarized the curriculum training plan for the voice program of popular songs according to the training plan for the performance major, the class schedule, interviews and questionnaires of teachers and students. It should be able to more comprehensive reflection of the status of voice program of popular songs in Southwest University (http://www.swu.edu.cn/).

\section{Research Objective}

The objective is to improve the construction of voice teachers in the pop singing direction about undergraduate stage in Southwest University.

\section{Research Methodology}

This is a qualitative investigation adopting the fieldwork. Data for this investigation were collected from both field work and documents analysis in Southwest University in China.

1) My populations are 6 top-rated normal universities with voice major of pop songs.

There are about 2879 universities in China. Therefore, we can do the research only in top-rated universities. Music major is in 11 Conservatory of Music, 6 Universities of Arts, numerous normal universities and numerous comprehensive universities. Only 6 normal universities are in 211 universities program, which is the construction facing the 21 st century, about 100 colleges and universities and a number of key disciplines. Only the 6 normal universities are under ministry of education in China, with long history of music faculty at the same time, which are Beijing Normal University, East China Normal University, Northeast Normal University, Central China Normal university, Southwest Normal University, Shanxi Normal University 6 normal universities. Only Northeast Normal University and Southwest Normal University offer voice major of pop songs. 
2) My sample is Southwest University. Southwest normal university was renamed southwest university in 2005, but it is still considered a normal university, because it has the characteristics of a normal university.

The field study includes collecting data, interviewing the teacher and the students, questionnaire for the students. Through the fieldwork in Southwest University, the author concludes the curriculum program of voice major of pop songs, which consists of curriculum objectives, curriculum requirements, length of schooling, minimum graduation credits and degrees awarded, course classification and credits distribution, composition of teaching staff, enrollment, course evaluation.

The author finished the 6 steps about this kind of research: Introduction and problem presentation; Establish the thesis; Field research (questionnaire, interview, data collection, literature analysis); Classification and Summarization; Presentation of the ideas; Conclusion and recommendation.

\section{Results}

Research and efforts have been made on the curriculum program, and the construction of voice teachers are showed in the pop singing direction in Southwest University in Table 1 and Table 2.

The results of the study were found as follows:

1) The educational structure of full time teachers in pop song direction of voice major needs to be improved, which is not balanced. Currently, the direction of popular music in music performance department in Southwest University has 3 voice teachers, 1 is full time teacher, who is Master degree, accounting for $33 \%$, and 2 are part-time teachers, who are Bachelor degree, accounting for $66 \%$. In May, 2019, there are 9 senior students, 11 junior students, 8 sophomore, and 5 freshmen in pop song direction of voice teacher. For 33 students, 1 full time teacher is not enough, whose position is lecturer, and the ratio between the full time voice teacher and the students is 1:33 (http://www.swu.edu.cn/).

Table 1. Proportion of the full time teachers in pop singing direction in Southwest University.

\begin{tabular}{ccccccc}
\hline University Name & Teacher Category & $\begin{array}{c}\text { Teacher } \\
\text { Number }\end{array}$ & $\begin{array}{c}\text { Education } \\
\text { Background }\end{array}$ & Position & Proportion \\
\hline \multirow{2}{*}{ Southwest University } & Full time teachers & 1 & Master & Lecturer & $33 \%$ \\
& Part time teachers & 2 & Bachelor & Lecturer & $66 \%$ \\
\hline
\end{tabular}

Table 2. Ratio about voice teachers and the students in pop singing direction in Southwest University.

\begin{tabular}{ccccc}
\hline University Name & Teacher Category & Teacher Number & Students Number & Ratio \\
\hline & Full time teachers & 1 & 33 & $1: 33$ \\
Southwest & Part time teachers & 2 & 33 & $1: 16.5$ \\
University & Total & 3 & 33 & $1: 10$ \\
\hline
\end{tabular}


2) The comprehensive quality of the teachers needs to be promoted. The full time voice teacher has been the staff in the office to manage the students, not to be a teacher, without Ph.D degree. And 2 part time teachers never stayed in art troupe, lack of comprehensive performing experience, without Master $₫$ degree. Their professional experience is not suitable for cultivating versatile pop singers.

3) The reserve of knowledge needs be broadened. The knowledge structure of full-time teachers and part-time teachers comes from classical music, which lacks the multifunctional teaching ability of pop singing subjects. The part-time teachers with unstable characteristics, is not conducive to the expansion of knowledge, who cannot meet the needs of the cultivation of popular singing specialty talents.

\section{Findings}

1) Due to the lack of full-time vocal music teachers in the popular direction in Southwest University, it does not have the characteristics of balanced structure of ages, the structure of education background and professional post. Since there is a shortage of people with both Ph.D degree and a senior professional post in pop singing in China, universities and colleges need to bring in Ph.D degree teachers and give them a senior professional post policy preference.

2) According to the educational background and working experience of the full time teachers and part time teachers in the pop singing direction in Southwest University, they do not have the comprehensive ability to teach the popular singing direction. Teachers should enjoy various forms of continuing education, including on-the-job Master's and doctoral studies, visiting scholars at home and abroad, scientific research projects.

3) Due to their learning and working experiences, the vocal music teachers in the direction of pop singing in Southwest University lack the professional characteristics and multi-functional abilities of the pop singing. When teaching professional skills, teachers need to stimulate students' learning and understanding ability, to impart knowledge and skills. Therefore, if teachers with part of professional skills and knowledge of pop singing, do not enrich their knowledge structure and strengthen their cultural accomplishment, it is difficult to meet the training needs of the market of pop singing talents.

\section{Discussion}

Through literature review, the article Teaching Practice of Popular Music in Universities in Multicultural Context, the author takes the popular music singing major of Nanjing Art University as the research object. And the present situation, teaching system and various practices of this major are comprehensively and deeply expounded and analyzed, without fieldwork. However, there is no study on the construction of voice teachers in pop songs.

The faculty building of teaching staff is the key to the cultivation of special talents in pop singing. At present, there are not many pop singing teaching tal- 
ents in China. Therefore, the construction of current pop singing teachers in Southwest University should be improved and promoted, which is showed as follows, and alleviate the shortage of teachers in Southwest University, meet the need to improve their professional level (Table 3).

Firstly, it is to promote the educational level of teachers and improve the structure of teachers of pop singing direction in Southwest University. From the perspective of social development and the market demand for pop singers, it has shown the tendency of demand for different types of high-level pop singers. With the growing demand and requirements for the cultivation of talents of different types of pop singing, the structure of the teaching staff to cultivate high-level and multi-type pop singers needs to be constantly improved. The overall function of pop singing teachers in Southwest University also needs to be further improved.

In terms of structure about age, a reasonable proportion of teachers of the old, middle and young ages should be considered, when Southwest University introduce and employ pop singing talents. To ensure that the age structure of teachers can develop towards younger age, a discipline echelon should be formed with young and middle-aged backbone teachers as the main body and modern advanced teaching concepts.

In terms of educational structure, at present, the educational background of pop singing teachers in Southwest University is generally not high. To some extent, the academic structure determines the overall theoretical level, teaching quality and scientific research ability of the teaching staff. Therefore, it is imperative to improve the educational level of pop singing teachers in normal universities. All young teachers should be encouraged and supported to improve their educational level through further education, to improve the educational structure of the teaching staff.

Table 3. Suggestions about construction of voice teachers in pop singing direction in Southwest University.

\begin{tabular}{|c|c|}
\hline Category & Suggestions \\
\hline The structure of the teachers & $\begin{array}{ll}\text { - } & \text { Rational proportion of ages; } \\
\text { - } & \text { High requirements of education background; } \\
\text { - } & \text { Reasonable structure of professional posts; }\end{array}$ \\
\hline $\begin{array}{c}\text { The comprehensive quality } \\
\text { of the teachers }\end{array}$ & $\begin{array}{l}\text { - On-the-job master, doctoral study; } \\
\text { - } \quad \text { Visiting scholars at home and abroad; } \\
\text { - } \quad \text { Scientific research projects; }\end{array}$ \\
\hline $\begin{array}{l}\text { The knowledge and skills } \\
\text { broadening of the teachers }\end{array}$ & $\begin{array}{l}\text { - To continue to improve the professional level; } \\
\text { - To design a reasonable and specific training objectives for } \\
\text { each student; } \\
\text { - To stimulate students' ability of learning and } \\
\text { understanding; } \\
\text { - To attach importance to the theoretical knowledge related } \\
\text { to pop singing and the interdisciplinary knowledge with } \\
\text { pop singing. }\end{array}$ \\
\hline
\end{tabular}


In terms of the structure of professional titles, a fair evaluation and employment mechanism should be established. To formulate the detailed rules of professional title assessment in line with the actual situation of our university, and to provide more opportunities for exchange and learning for the majority of young teachers and teachers of emerging disciplines, the staff should stick to the method of internal training and external recruitment, to stabilize the existing backbone teachers and train new academic leaders; to ensure the improvement of teachers' teaching level and improve the scientific research ability of teachers, which ensure that teachers reach a higher level of medium and high professional posts.

In a word, according to our national conditions, we should take practical and feasible measures to strengthen the cultivation of teachers of pop singing in Southwest University at the level of higher education. Therefore, those high-level talents with deep cultural quality, high professional level and strong professional ability should be constantly enriched into the teaching staff of pop singing talent cultivation in Southwest University, so that the teacher structure is improved.

Secondly, it is to advocate multi-channel training to comprehensively improve the comprehensive quality of teachers of pop singing direction in Southwest University.

High quality teachers are the foundation of high quality education, and lifelong education is the condition to guarantee high quality teachers (Guan, 2005). On one hand, pop singing teachers in Southwest University must have good professional quality and profound knowledge. On the other hand, the teachers should know how to use appropriate teaching methods to improve the teaching effect. Moreover, teachers must use the modernized teaching equipment skillfully.

Therefore, teachers of pop singing in Southwest University should spend their spare time to read and study more about pop singing, to strengthen training. To improve comprehensive quality comprehensively, teachers' professional training should be the breakthrough point to fully explore and utilize the potential of pop singing teachers, to promote its continuous reflection and improvement. According to the professional development needs, teachers should enjoy various forms of continuing education, not to affect work.

If an independent art university has various teacher training programs, to conduct on-the-job master studies and doctoral studies, and conduct domestic and foreign visiting scholars and research projects, etc. On the one hand, it provides opportunities for young teachers to further study systematically. On the other hand, it also creates favorable conditions for the promotion of their professional post. In the foreign teacher's continuing education aspect, the science and technology culture developed has formed the quite complete system. For example, in the former Soviet Union, since the end of the 1970s, more than 40 institutions of higher learning have established further education departments in new subject areas. Most of the students enrolled are those aged between 25 and 35 with an actual working age of 3 to 8 years. Some states in USA also use their 
vacations to organize art teachers to attend extensive classes. These multi-channel training forms can also be used in the training of pop singing professional teachers. Resources and experience sharing should be strengthened between universities and teachers, as soon as possible to improve the professional level of pop singing teachers.

Thirdly, it is to make clear role positioning and broaden teachers' knowledge and skills reserve (Haberster, 2013). Pop singing teachers in Southwest University should make clear their role positioning, One is to ensure that their professional level to constantly improve; The other is to clarify the requirements for the cultivation of pop singers and combine them with the actual level of students, make reasonable and specific training objectives for each student. Moreover, the teachers should stimulate students' ability of learning and comprehension when teaching professional skills, to understand the techniques of imparting knowledge.

From the perspective of knowledge structure, teachers of popular singing in Southwest University should have the characteristics of one specialty with multifunctional abilities. The so-called one specialty refers to a singing skill that is good at pop singing, and multifunctional abilities refer to the knowledge related to pop singing art should be mastered. For example, in the course of comprehensive theory of pop singing, teachers should be familiar with knowledge of relevant subjects such as philosophy, aesthetics, culture, psychology, and so on, besides singing, playing and dancing.

Therefore, pop singing teachers should not only have certain professional skills in pop singing, but also a relatively deep and broad theoretical basis. The richer the teacher's knowledge is, the more artistic is in the classroom, and the better the teaching effect is. The author thinks that teachers generally accept the comprehensive concept of subject but it is difficult to implement, which is largely due to the limitation of teachers' own cultural quality. It is difficult for a pop singing teacher with incomplete knowledge structure and lack of cultural foundation to realize the subject integration in pop singing teaching. Although it is impossible for a teacher to master every subject, the teacher's knowledge should be as broad as possible, to pay more attention to subjects other than art, such as common sense in the natural sciences and social sciences, so as to make oneself more broad knowledge field of vision. In this way, teachers can target in the process of guiding students.

Due to the long-standing misunderstanding and prejudice on pop singing education in China, it is also the main reason that the knowledge structure of pop singing teachers is relatively single. All the time, the training of pop singing teachers is more in line with professional skills. Theoretical knowledge related to art education, such as general pedagogy, psychology and pedagogy, is often hard to be valued. Therefore, to train the pop singing teachers comprehensive artistic quality and cultural quality is neglected. As a result, the teachers trained are not guaranteed with quality while the educational quality is weak. Especially in pop singing research teaching, teachers will feel the lack of their own educational 
ability. Students in the new era tend to have higher cultural attainment with a wide range of knowledge, that are interested in pop singing problems often involve a wide range of areas. Teachers who go into the front line of teaching often encounter this problem. For example, students often show a strong interest in interdisciplinary subjects of pop singing and other subjects, and ask some cross-subject questions, to make it difficult for teachers to deal with. Therefore, the comprehensiveness of pop singing makes teachers a broad and rich range of knowledge. Not only should teachers have a comprehensive knowledge of pop singing professional skills, but also understand the theoretical knowledge related to pop singing and the interdisciplinary basic knowledge with pop singing subjects. Therefore, if teachers do not enrich their own knowledge structure, either not to strengthen their own cultural cultivation, it is difficult to meet the training needs of pop singing talents with only some professional skills and knowledge of pop singing.

\section{Conclusion}

The design and implementation of curriculum is a complex, dynamic and developing system. The construction of teachers is an important part of curriculum implementation. Its development follows unbalanced to balanced, from balanced to new balanced, showing a tortuous upward trend. The structure of the teachers, the comprehensive quality of teachers, the knowledge and skills broadening of the teachers should be enhanced about voice teachers of pop songs in Southwest University, China. The author can only give some suggestions on the voice teacher of pop songs in Southwest University, and the further research of curriculum implementation could be explored in other universities. If the research results are used to solve the problems of voice teacher of pop songs in other universities, the characteristics of the program in other universities should be combined.

\section{Conflicts of Interest}

The author declares no conflicts of interest regarding the publication of this paper.

\section{References}

Guan, J. H. (2005). Postmodern Turn of German Music Pedagogy. Sichuan Conservatory of Music Journal, 4, 91.

Haberster (2013). Reference and Enlightenment of Music Teaching System Abroad. Journal of Neimeng Normal University, 26, 153. 